\title{
Synergistic effect of Bacillus isolates and biomass ash on soil and plant quality: A preliminary pot- experiment with the analysis of potentially toxic elements
}

Aneta Buntić*, Sonja Tošić Jojević, Magdalena Knežević, Marina Jovković, Biljana Sikiric, Nikola Koković, Elmira Saljnikov

${ }^{1}$ Institute of Soil Science, Teodora Drajzera 7, 11060 Belgrade, Serbia

*corresponding author: Aneta Buntić, anetabuntic@gmail.com

\begin{abstract}
The use of biomass ash in agriculture can have advantages such as improved soil quality and environmentally friendly ash disposal. Moreover, in combination with microbial inoculants, biomass ash can have a beneficial effect on plant growth. The study investigated the effect of biomass ash and inoculums of three Bacillus isolates on the quality of soil and barley plants. The greenhouse pot experiment included five treatments and two control soils: control - without any amendment and control with mineral fertilizer $(\mathrm{CAN})$. Treatments included soil $(3 \mathrm{~kg} / \mathrm{pot})$ and biomass ash $(30 \mathrm{~g} / \mathrm{pot})$ with and without calcium ammonium nitrate or with bacterial inoculum. Biomass ash was collected after combustion of soybean straw. Bacillus sp. were isolated from the rhizosphere soil of alfalfa. The presence of PGP traits (Indole-3Acetic Acid and siderophores) was confirmed by the quantitative tests for the three Bacillus isolates used (B1, BS1, BMG1). The ash, soil and plant (collected in crop maturity stage) samples were tested for: total $\mathrm{N}, \mathrm{C}, \mathrm{S}$, and plant available $\mathrm{P}_{2} \mathrm{O}_{5}$ and $\mathrm{K}_{2} \mathrm{O}$ as well as for the content of potentially toxic and hazardous microelements ( $\mathrm{As}, \mathrm{Cd}, \mathrm{Co}, \mathrm{Cr}, \mathrm{Cu}, \mathrm{Mn}, \mathrm{Ni}, \mathrm{Pb}, \mathrm{Zn}$ ). Inoculation of seeds with Bacillus inoculums (in vitro) showed a significant effect on seedling growth compared to the non-inoculated control. Addition of ash significantly reduced soil acidity and increased content of plant available $\mathrm{P}$ and $\mathrm{K}$ compared to the controls, while combination of ash and microorganism, increased amount of available P compared to the treatment with ash only. Barley biomass yield was increased more than double when treated with ash and by $87.62 \%$ when treated with ash+BMG1 compared to control. The lowest yield was obtained in the treatment where only CAN was added. The content of potentially toxic microelements in the soil and barley shoots was below the maximum allowed concentrations. The use of biomass ash alone was effective in terms of soil nutritional and physical properties resulting in yield increase. However, the use of ash in combination with Bacillus isolates in addition to positive effect on soil and plant quality resulted in a higher barley biomass than the combination of ash with CAN. This study showed that biomass ash can be used as fertilizer on acidic soils with low nutrient content alone or in combination with bacterial inoculants. The synergistic effect of ash with microorganisms can provide an environmentally friendly approach in agriculture to reduce the need for chemical fertilizers and solve the problem of biomass ash disposal.
\end{abstract}

Keywords: Bacillus, biomass ash, soil, barley, nutrient, trace elements 


\section{Introduction}

Nowadays, the use of biomass from agricultural fields as an alternative source for heat and electricity production is increasing (Zhang et al. 2018; Saljnikov et al. 2018). Their application in thermo-chemical processes contributes over $90 \%$ of the total global bioenergy, but on the other hand, these processes also generate a large amount biomass ash (Zhang et al. 2018; Loo and Koppejan, 2008). The ash of the agricultural biomass contains most of the nutrients (potassium, phosphorus, calcium, magnesium, and etc.) for plant growth (Pesonen et al., 2016). A large part of biomass ashes are disposed as landfills and its potential remains untapped. Utilization of biomass ash in an environmentally friendly and cost effective way is an important goal (Saljnikov et al. 2018).

An intensive agricultural system in which crop residues are harvested for energy rather than returned to the soil leads to a rapid depletion of nutrients in the soils. Sustainable management of such ecosystems is very important, and the return of biomass ash to the fields can partially compensate for the loss nutrients from the soil. On the one hand, biomass ash can be reused as fertilizer or soil ameliorant (Brannvall et al. 2015; Freire et al. 2015), and on the other hand, it would reduce the amount of waste to be disposed of, as well as the amount of chemical fertilizer (Zhang et al. 2018).

Recently, the possibility of utilization of biomass ash as fertilizer has attracted many researchers. Most of the studies focus on determining the nutrient content of biomass ash and the effect of ash on plant growth. In addition, biomass ash can improve soil characteristics such as soil $\mathrm{pH}$ for acidic soils and texture for heavy soils, thereby creating better conditions for soil microorganisms. Combining biomass ash with plant growth promoting (PGP) rhizobacteria may have good potential for soil remediation and for improving plant growth in poor soils. However, apart from the potential nutritional value, biomass ash may contain potentially toxic and dangerous elements. Therefore, the use of biomass ash should be adjusted in such a way as to ensure that toxic elements do not contaminate the soil and plants, and its nutrient content is balanced (Zhang et al. 2018; Brannvall et al., 2014).

The main objective of this research was studying the possibilities of utilization of biomass ash obtained by combusting soybean post-harvest residues. The tasks included studying the effects of ash addition alone and in combination with Bacillus isolates and their effect on soil and barley (Hordeum sativum) quality. In addition, the plant growth promoting traits and the germination of inoculated barley seed with Bacillus isolates was examined. The main goal was to find an appropriate scheme for biomass ash utilization in order to improve the quality of soil and at the same time reduce the environmental problem of ash disposal. 


\section{Material and Methods}

Sample materials

The biomass ash was collected after combustion of soybean biomass for energy purposes at the Agricultural Corporation PKB Belgrade. The content of nutritive elements ( $, C, S, C a C O 3, \mathrm{P}_{2} \mathrm{O}_{5}$ and $\left.\mathrm{K}_{2} \mathrm{O}\right)$, as well as the content of potentially toxic and hazardous microelements (PTE; As, $\mathrm{Cd}, \mathrm{Co}, \mathrm{Cr}, \mathrm{Cu}, \mathrm{Mn}, \mathrm{Ni}, \mathrm{Pb}$ and $\mathrm{Zn}$ ) in biomass ash were analyzed. The experimental soil was acidic and poor in nutrients Cambisol (WRB 2015). The Bacillus isolates B1, BS1 and BMG1 used in this research were isolated form rhizosphere soils gathered from local grassland. Soil sample was diluted to $10^{-6}$, and heated on $80^{\circ} \mathrm{C}$ during 15 min to isolate Bacillus spores (Buntić et al. 2019; Knežević 2019).

\section{PGP traits and seed germination}

Phosphate solubilization (insoluble) was tested using Pikovskaya medium (Rokhbakhsh-Zamin et al. 2011) and the appearance of halo zone around the colony $\left(7\right.$ days, $\left.28^{\circ} \mathrm{C}\right)$ was a positive test. Siderophore production was determined by Chrome Azurol S (CAS) Blue agar plate assay (Milagres et al. 1999). Bacterial cultures were spot inoculated onto plates, incubated $\left(28^{\circ} \mathrm{C}, 5\right.$ days $)$ in the dark and the appearance of yellow halo zone around the colony presented a positive test for siderophores production. The ability of bacterial isolates to produce indol-acetic acid (IAA) was tested in nutrient media enriched with $2 \mathrm{mg} / \mathrm{mL}$ tryptophan, based on the method previously described by Stajković et al. (2011). All tests were done in triplicate.

The ability of Bacillus isolates to improve germination of barley seeds was performed in vitro on Petri dishes in a transparent sealed box in a light chamber programmed for a $16 / 8 \mathrm{~h}$ at $22^{\circ} \mathrm{C}$. An aliquot of $1.0 \mathrm{~mL}$ of overnight bacterial culture (B1/BS1/BMG1) was added to the microtube with 20 seeds. The mixture was agitated and alfalfa seeds were placed onto filter paper in Petri dishes which previously moistened with $1 \mathrm{~mL}$ of sterile distilled water. The control sample consisted of barley seeds, without any bacterial treatment applied. The experiment was performed for one week in two independent repetitions and the results were averaged. The results were expressed by shoot and root length and final seed germination percentage (FG\%) (Ali et al. 2015):

$$
\mathrm{FG}(\%)=\frac{\mathrm{SG}_{\mathrm{s}}}{\mathrm{PS}_{\mathrm{tot}}} \times 100
$$

where $\mathrm{SG}_{\mathrm{S}}$ is germinated seeds in samples and $\mathrm{PS}_{\text {tot }}$ is total planted seed. 


\section{Pot experiment}

The pot experimental scheme included seven treatments, each in three replications: 1 .control - soil without any amendment; 2. control+CAN - 0.3 g CAN (CAN, calcium ammonium nitrate, with $27 \%$ of N); 3 . ash (30 g/pot); 4. ash+CAN; 5. ash+B1; 6. ash+BS1; 7. ash+BMG1. Each treatment, including controls, was performed in a pot with $3 \mathrm{~kg}$ of soil. Every second day, each pot was weighed and watered if necessary to keep the 50\% field moist capacity. In each pot 15 grains of barley was seeded. After germination the number of plants was reduced to 10 per pot. $1.0 \mathrm{~mL}$ of Bacillus overnight culture was added to treatments 5-7 two weeks after sowing. At the end of the experiment the soil was analyzed for the content of PTE and main agrochemical properties. Barley biomass in crop maturity stage was collected followed by determination of plant shoot dry weight (SDW) and the content of the same microelements and nutrients in SDW.

\section{Soil and plant sample analysis}

Soil $\mathrm{pH}$ was determined with a glass electrode $\mathrm{pH}$ meter in $1 \mathrm{~mol} \mathrm{~L}^{-1} \mathrm{KCl}(\mathrm{pH} \mathrm{KCl}$; in ratio 1:2.5 (w/v)) and in distilled water ( $\mathrm{pH} \mathrm{H}_{2} \mathrm{O}$; in ratio 1:20 (w/v)) (SRPS ISO 11464:2004). The content of $\mathrm{N}$ and $\mathrm{C}(\%)$ in the soil sample was measured on an elemental CNS analyzer (Vario model EL III -ELEMENTAL Analysis systems GmbH, Hanau, Germany) (Nelson and Sommers, 1996). Content of inorganic carbon $\left(\mathrm{CaCO}_{3}\right)$ was determined volumetrically with a Scheibler calcimeter, whereas the total organic carbon $\left(\mathrm{C}_{\text {toc }}\right)$ was calculated according to the equation: $\mathrm{C}_{\mathrm{toc}}=\mathrm{C}_{\text {tot }}-\mathrm{CaCO}_{3}$. Available $\mathrm{P}$ and $\mathrm{K}$ in the soil were determined by the Al-method (Riehm, 1958), where $0.1 \mathrm{~mol} / \mathrm{L}$ ammonium lactate $(\mathrm{pH}=3.7)$ was used as an extract. After extraction, $\mathrm{K}_{2} \mathrm{O}$ was determined by a flame emission photometry and $\mathrm{P}_{2} \mathrm{O}_{5}$ by spectrophotometer after color development with ammonium molybdate and $\mathrm{SnCl}_{2}$. Trace elements content in the soil was determined using inductively coupled plasma-atomic emission spectrometry ICP-OES (iCAP 6300 Duo, THERMO) after digestion of the samples with aqua regia according to SRPS ISO 11466.

Samples of the plant material were dried and milled using grinding mill (Miller, 1998). Then after digestion with concentrated $\mathrm{HNO}_{3}$ and $30 \% \mathrm{H}_{2} \mathrm{O}_{2}$, total trace elements and macroelements $\left(\mathrm{K}_{2} \mathrm{O}\right.$ and $\left.\mathrm{P}_{2} \mathrm{O}_{5}\right)$ were determined with THERMO iCAP 6300 Duo ICP-OES. The total $\mathrm{N}$ and $\mathrm{C}$ contents were determined using elemental CNS analyzer, Vario model EL III (Horneck and Miller, 1997).

\section{Statistical analysis}

The effects of pre-inoculation of alfalfa seeds were evaluated by one way ANOVA followed by post hoc Duncan's test to examine the differences between each treatment. 


\section{Results and discussion}

Isolates B1, BS1 and BMG1 belonging to the genus Bacillus according to the cell morphology and Gram staining (Gram-positive, rod-shaped bacteria, Figure 1).

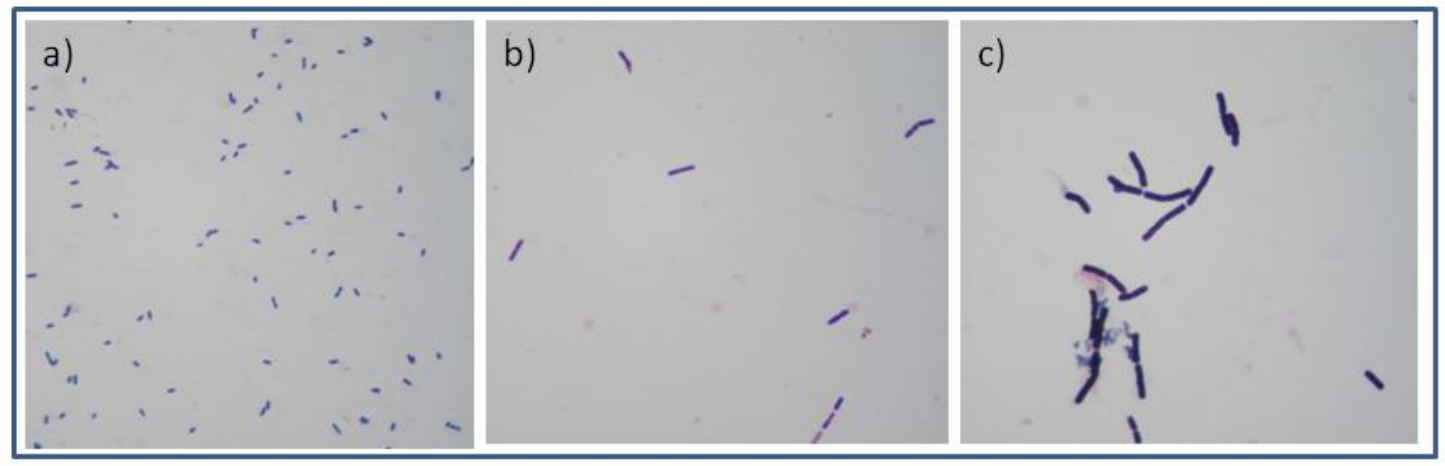

Figure 1. Microscopic preparations of Bacillus isolates: a) B1, b) BS1, c) BMG1.

The results of possession of PGP traits, such as siderophores, phosphate solubilization and IAA, are presented in Table 1. All isolates are capable to soluble phosphates, produce siderophores and IAA. The biggest yellow halo zone was given by isolate $\mathrm{B} 1$, while the $\mathrm{BS} 1$ isolate produced the most IAA.

Table 1. Plant growth promoting traits of Bacillus isolates

\begin{tabular}{cccc}
\hline Bacillus isolate & $\begin{array}{c}\text { Siderophores } \\
(\mathrm{cm})\end{array}$ & Phosphate solubilization & $\begin{array}{c}\text { IAA* } \\
(\mu \mathrm{g} / \mathrm{mL})\end{array}$ \\
\hline B1 & $21 \pm 2.65$ & + & $1.92 \pm 0.12$ \\
BS1 & $7 \pm 0.87$ & + & $5.93 \pm 0.22$ \\
BMG1 & $1 \pm 0.50$ & + & $3.85 \pm 0.27$ \\
& & (Buntić et al. 2019) \\
\hline
\end{tabular}

$*_{\text {- }}$ in the presence of tryptophan $(2 \mathrm{mg} / \mathrm{mL})$

The effect of Bacillus isolates B1, BS1 and BM1 on barley seed germination parameters are presented in Table 2. All planted seeds germinated after inoculation with used inoculums while the final seed germination in non-inoculated control was $95 \%$.

Inoculated seeds by all inoculums improved seed germination as shown by longer shoot and root length. According to ANOVA analysis significant difference were observed between treatments for root $(P<0.001)$ and shoot length $(P<0.001)$ (Table 2). Compared to the control, all treatments significantly increased the length of root and shoot, according to the Duncan test. Treatment B1 had the greatest effect on stimulating seedling growth and increased root length by about 2.30 times and shoot length by about 2.19 times, compared to the control sample. Improving seedling growth may be related to the ability of B1 strain to produces IAA, siderophores and to solubilise phosphate. Several studies have shown that bacteria with these PGP traits could enhance seedling growth (Knežević et al. 2021; Pandey and Gupta, 2020). 
Table 2. The effect of Bacillus isolates on the length of shoot and root of Hordeum sativum seed

\begin{tabular}{cccc}
\hline \multirow{2}{*}{ Seed treatment } & \multicolumn{3}{c}{ Parameters } \\
\cline { 2 - 4 } & $\begin{array}{c}\text { FG } \\
(\%)\end{array}$ & $\begin{array}{c}\text { Root length } \\
(\mathrm{cm})\end{array}$ & $\begin{array}{c}\text { Shoot length } \\
(\mathrm{cm})\end{array}$ \\
\hline Control & 95 & $3.58 \pm 0.57^{\mathrm{c}}$ & $4.25 \pm 0.41^{\mathrm{b}}$ \\
B1 & 100 & $8.25 \pm 1.14^{\mathrm{a}}$ & $9.30 \pm 0.66^{\mathrm{a}}$ \\
BS1 & 100 & $7.85 \pm 0.83^{\mathrm{ab}}$ & $9.05 \pm 0.69^{\mathrm{a}}$ \\
BMG1 & 100 & $7.50 \pm 0.76^{\mathrm{b}}$ & $9.14 \pm 0.75^{\mathrm{a}}$ \\
(Buntić et al. 2019) & & $129.997^{* * *}$ & $298.524^{* * *}$ \\
\hline ANOVA & &
\end{tabular}

FG-final seed germination percentage; Values present mean value with standard deviation followed by the same letter in the column are not significantly different (Duncan's test, $P<0.05$ ). One-way ANOVA shows $F$-values; *** Significant at $P<0.001$.

The agrochemical characteristic of experimental soil and biomass ash are presented in Table 3. Cambisol studied was acidic and poor with organic carbon while biomass ash characterized with alkaline soil $\mathrm{pH}$ and high content of $\mathrm{K}_{2} \mathrm{O}$ and $\mathrm{P}_{2} \mathrm{O}_{5}$. The content of $\mathrm{N}$ in the Cambisol was about two times lower than in the biomass ash. Content of potentially toxic microelements in the biomass ash (Table 6) were below of maximum allowed concentrations (MAC) and were comparable to the reported in Austria for most of the cases (Obernberger and Supancic, 2009).

Table 3. Agrochemical properties of experimental soil and biomass ash

\begin{tabular}{|c|c|c|c|c|c|c|c|}
\hline & \multicolumn{2}{|c|}{$\mathrm{pH}$} & \multirow{2}{*}{$\begin{array}{c}\mathrm{C}_{\mathrm{a}} \mathrm{CO}_{3} \\
\%\end{array}$} & $\mathrm{P}_{2} \mathrm{O}_{5}$ & $\mathrm{~K}_{2} \mathrm{O}$ & \multirow{2}{*}{$\begin{array}{c}\mathrm{N} \text { content } \\
\%\end{array}$} & \multirow{2}{*}{$\begin{array}{c}\mathrm{C} \text { content } \\
\%\end{array}$} \\
\hline & $\mathrm{H}_{2} \mathrm{O}$ & $\mathrm{KCl}$ & & \multicolumn{2}{|c|}{$\mathrm{mg} / 100 \mathrm{~g}$} & & \\
\hline Cambisol & 5.5 & 4.3 & 0 & 2.8 & 12.3 & 0.12 & 1.38 \\
\hline Biomass ash & 12.6 & 12.6 & 0 & 526.30 & 5391.35 & 0.26 & 4.27 \\
\hline
\end{tabular}

After harvesting of barely the soil pH significantly increased due to addition of biomass ash (Table 4). This increase was expected as shown by previous preliminary research (Saljnikov et al. 2018). In the control soils (control and control+CAN), the $\mathrm{pH}$ (in $\mathrm{KCl}$ and $\mathrm{H}_{2} \mathrm{O}$ ) remained unchanged. The amount of plant available $\mathrm{P}$ and $\mathrm{K}$ in the control soils also remained unchanged, presumably because the amount of assimilated nutrients by plants was negligible to cause significant changes in these parameters. At the end of the experiments, the amounts of $\mathrm{P}_{2} \mathrm{O}_{5}$ and $\mathrm{K}_{2} \mathrm{O}$ in the ash-added soils significantly increased compared to the controls. With an increase in $\mathrm{pH}$ and a decrease in soil acidity, a large part of phosphorus was transferred from poorly soluble compounds to soluble forms (Sikirić et al. 2015; Stevanović et al. 2002; Dugalić et al. 2006). The highest amount of available $\mathrm{P}$ was obtained in the soils of the treatments with addition of Bacillus isolates, followed by ash and ash+CAN. The amount of available phosphorus increases as the soil $\mathrm{pH}$ decreases, which is observed in ash+BMG1 treatment (Table 4). This increase could be due to the solubilisation of insoluble phosphorus by Bacillus isolates (Table 1). Similarly, Cakmakci et al. (2007) noted same changes in the amount of available phosphorus and $\mathrm{pH}$ in soil after harvesting barley 
that was inoculated with B. megaterium RC01 and Bacillus M-13. The content of total $\mathrm{N}$ did not change in the ash amended treatments compared to the control, while the content of total $\mathrm{C}$ was positively affected by addition of ash (Table 4). The highest significant increase in total $\mathrm{C}$ content was observed in Ash and Ash+BS1 treatments. The addition of fertilizer, as expected, led to an increase in the belowground and aboveground crop biomass, which contributed to the carbon stock in the soil. The biomass ash used contained $4.27 \%$ carbon the addition of which to the soil with $1.38 \%$ carbon resulted in a positive and significant increase in the total soil carbon. Saletnik et al. (2018) also found that addition of biomass ash combined with biochar fertilizer significantly increased total soil carbon compared to control. But the same authors reported that the total nitrogen content decreased significantly in all treatments compared to the control soil. In our study, the nitrogen content increased slightly in most of the ash amended and fertilized treatments, which indicates that the uptake of the soil mineral $\mathrm{N}$ by plants was replenished by the addition of fertilizer or ash and microorganism isolates.

Table 4. Agrochemical characteristics of the soil after barley biomass harvest

\begin{tabular}{ccccccc}
\hline Treatment & \multicolumn{2}{c}{$\mathrm{pH}$} & $\mathrm{N}$ content & $\mathrm{C}$ content & $\mathrm{P}_{2} \mathrm{O}_{5}$ & $\mathrm{~K}_{2} \mathrm{O}$ \\
& $\mathrm{H}_{2} \mathrm{O}$ & $\mathrm{KCl}$ & \multicolumn{2}{c}{$(\%)$} & \multicolumn{2}{c}{$\mathrm{mg} / 100 \mathrm{~g}$} \\
\hline Control & $5.50 \mathrm{c}$ & $4.33 \mathrm{c}$ & $0.120 \mathrm{ab}$ & $1.15 \mathrm{~b}$ & $2.79 \mathrm{~b}$ & $11.30 \mathrm{~b}$ \\
Control+CAN & $5.50 \mathrm{c}$ & $4.37 \mathrm{c}$ & $0.122 \mathrm{ab}$ & $1.26 \mathrm{ab}$ & $4.34 \mathrm{~b}$ & $13.31 \mathrm{~b}$ \\
Ash & $7.73 \mathrm{~b}$ & $7.48 \mathrm{a}$ & $0.133 \mathrm{a}$ & $1.27 \mathrm{a}$ & $98.72 \mathrm{a}$ & $281.40 \mathrm{a}$ \\
Ash+CAN & $7.88 \mathrm{a}$ & $7.42 \mathrm{ab}$ & $0.123 \mathrm{ab}$ & $1.25 \mathrm{ab}$ & $98.22 \mathrm{a}$ & $256.20 \mathrm{a}$ \\
Ash+B1 & $7.88 \mathrm{a}$ & $7.48 \mathrm{a}$ & $0.127 \mathrm{ab}$ & $1.22 \mathrm{ab}$ & $107.88 \mathrm{a}$ & $284.90 \mathrm{a}$ \\
Ash+BS1 & $7.72 \mathrm{~b}$ & $7.43 \mathrm{a}$ & $0.130 \mathrm{ab}$ & $1.27 \mathrm{a}$ & $103.08 \mathrm{a}$ & $261.43 \mathrm{a}$ \\
Ash+BMG1 & $7.65 \mathrm{~b}$ & $7.30 \mathrm{~b}$ & $0.117 \mathrm{~b}$ & $1.15 \mathrm{~b}$ & $123.77 \mathrm{a}$ & $303.93 \mathrm{a}$ \\
\hline
\end{tabular}

The same letter within a column signifies non-significant difference (Duncan's test, $P<0.05$ ).

The aboveground yield of barley significantly increased in ash-added treatments compared to the controls (Table 5 and Figure 2). The increase in the ash and ash+BMG1 treatments were 2.06 and 2.15 and 1.88 and 1.96 times higher than in the control and control+CAN treatments, respectively. Inoculated treatments gave a higher barley biomass compared to ash+CAN treatment. The Bacillus isolates used had a stimulating effect on barley growth and increased the barley shoot dry weight. This is probably associated with the production of plant growth promoting substances by the isolates (Knežević et al. 2021; Cakmakci et al. 2007). In all treatments, the amount of $\mathrm{P}_{2} \mathrm{O}_{5}$ and $\mathrm{K}_{2} \mathrm{O}$ in the dry mass of barley shoot increased in comparison with the controls. In ash+BS1 and ash+BMG1, the increase was 1.95 and 1.58 times compared with the control, respectively. The content of $\mathrm{N}$ and $\mathrm{C}$ in dry mass of barley shoots was significantly higher in ash+B1 and ash+BS1 compared with the ash only treatment and the controls. The response of barley to these rhizobacteria could be related to mechanisms that do not involve direct fixation of $\mathrm{N}$, such as interaction of plants and isolates in the utilization of nitrates from the soil and increasing the availability of 
nitrogen for plants, as well as the production of hormones through which PGPR stimulates plant growth (Ozturk et al., 2003; Cakmakci et al., 2007).

Table 5. Content of main nutrients in barley shoot dry weight (SDW) and biomass yield

\begin{tabular}{lccccc}
\hline \multicolumn{1}{c}{ Treatment } & $\mathrm{N}$ content & $\mathrm{C}$ content & $\begin{array}{c}\mathrm{P}_{2} \mathrm{O}_{5} \\
(\mathrm{mg} / \mathrm{kg} \text { d.w. plant biomass) }\end{array}$ & $\begin{array}{c}\mathrm{K}_{2} \mathrm{O} \\
\text { (g/pot d.w. plant) }\end{array}$ \\
\hline Control & $1.34 \mathrm{e}$ & $40.8 \mathrm{a}$ & $4014 \mathrm{f}$ & $33183 \mathrm{~g}$ & $3.96 \pm 0.30 \mathrm{c}$ \\
Control+CAN & $1.98 \mathrm{c}$ & $39.4 \mathrm{~b}$ & $3583 \mathrm{~g}$ & $39129 \mathrm{f}$ & $3.79 \pm 0.53 \mathrm{c}$ \\
Ash & $1.91 \mathrm{~d}$ & $39.6 \mathrm{~b}$ & $8425 \mathrm{a}$ & $53703 \mathrm{~d}$ & $8.15 \pm 0.53 \mathrm{a}$ \\
Ash+CAN & $2.53 \mathrm{a}$ & $40.0 \mathrm{~b}$ & $8313 \mathrm{c}$ & $58135 \mathrm{a}$ & $7.06 \pm 0.20 \mathrm{~b}$ \\
Ash+B1 & $2.08 \mathrm{~b}$ & $40.0 \mathrm{~b}$ & $8377 \mathrm{~b}$ & $54871 \mathrm{~b}$ & $7.24 \pm 0.12 \mathrm{~b}$ \\
Ash+BS1 & $2.04 \mathrm{bc}$ & $39.8 \mathrm{~b}$ & $7833 \mathrm{e}$ & $53875 \mathrm{c}$ & $7.38 \pm 0.61 \mathrm{ab}$ \\
Ash+BMG1 & $1.86 \mathrm{~d}$ & $39.4 \mathrm{~b}$ & $8152 \mathrm{~d}$ & $52499 \mathrm{e}$ & $7.43 \pm 0.50 \mathrm{ab}$ \\
\hline
\end{tabular}

The same letter within a column signifies non-significant difference (Duncan's test, $\mathrm{P}<0.05$ ).
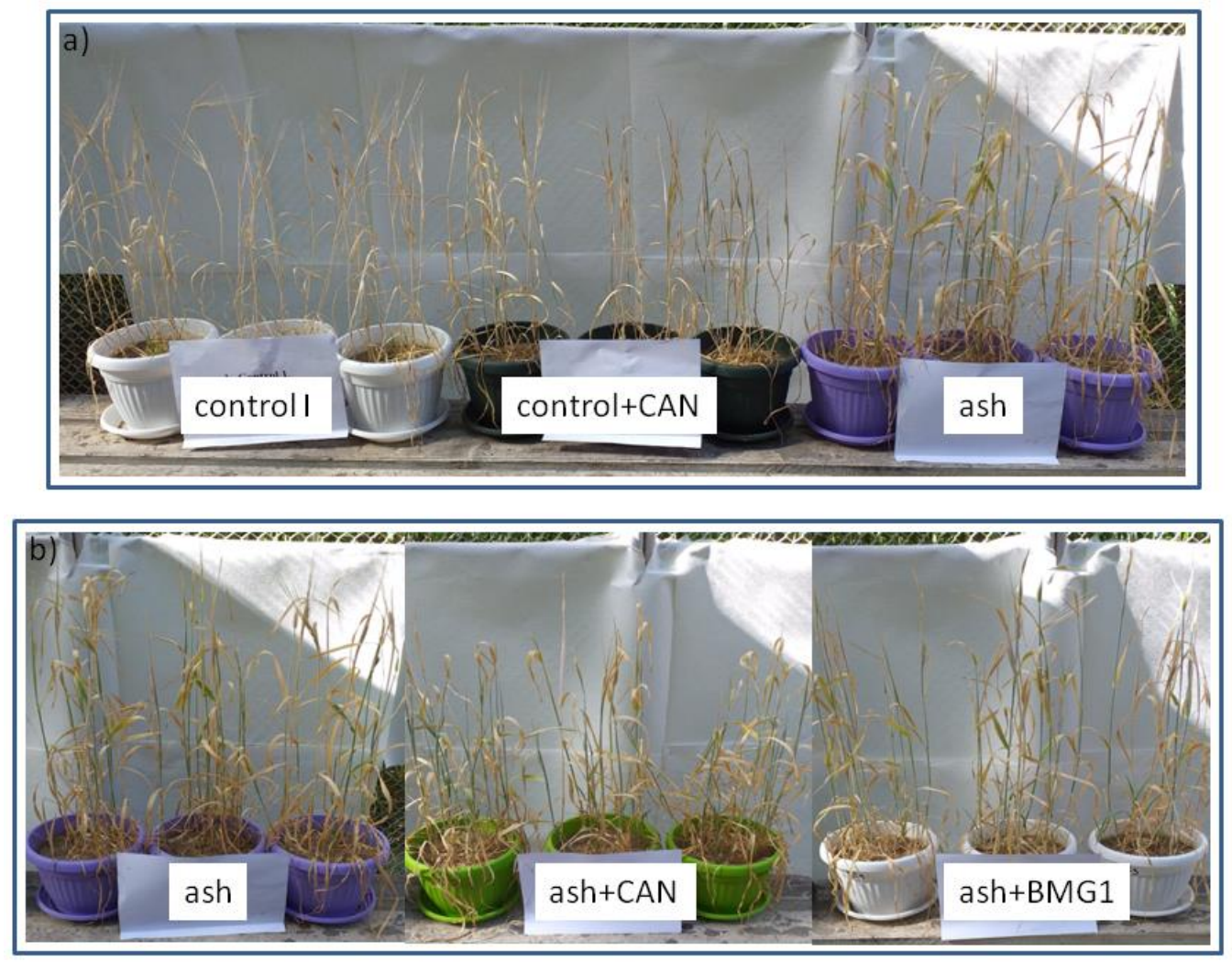

Figure 2. Pot experiment-barley plants at harvest stage: Comparison of ash treatment with: a) Control and Control CAN and b) Ash+CAN and Ash+BMG1treatments

The presence of trace elements in the biomass ash, soil and post-harvest plant is presented in Table 6. The solubility of most trace elements decreases in an almost neutral and alkaline substrate after adding ash to the soil (Sherene, 2010). At the end of the experiment, concentration of $\mathrm{As}, \mathrm{Cd}, \mathrm{Cr}, \mathrm{Cu}, \mathrm{Ni}, \mathrm{Pb}, \mathrm{Zn}$, $\mathrm{Mn}$ and $\mathrm{Co}$ in the treatments and control soils was lower than the maximum allowed concentrations (MAC) 
(Official Gazette of the Republic of Serbia No 23/94; Schulin et al., 2010; Adriano, 2001). The concentration of $\mathrm{Cu}$ was higher in the soils and plants of the treatments than in the corresponding controls. The observed changes in the content of copper in soil and plants were associated with changes in soil $\mathrm{pH}$ after ash addition. At higher $\mathrm{pH}, \mathrm{Cu}$ can be transformed into a more readily available plant form (Saljnikov et al. 2018, Cuske et al. 2013). There was observed an increase in the concentration of $\mathrm{Cd}, \mathrm{Cr}, \mathrm{Cu}$ and $\mathrm{Mn}$ in the treatment plants in comparison with the control. However, the content of trace elements in the plant samples did not exceed the MAC for feed (Official Gazette of the Republic of Serbia No 4/2010-30, 113/2012-11, 27/2014-17, 25/2015-85, 39/2016-41, 54/2017-29, Simić et al, 2015; Jakšić et al. 2013). Furthermore, this implies that the microorganisms used did not affect the higher uptake of trace elements by plant tissues.

Table 6. Content of trace elements in the experimental soil and plant after the harvest

\begin{tabular}{|c|c|c|c|c|c|c|c|c|c|}
\hline \multicolumn{10}{|c|}{ mg/kg d.w. soil } \\
\hline Control & 6.89 & 0.30 & 13.8 & 39.0 & 16.9 & 664 & 32.4 & 20.4 & 23.5 \\
\hline Control CAN & 6.38 & 0.29 & 13.2 & 38.2 & 16.2 & 640 & 31.6 & 19.8 & 23.2 \\
\hline Ash & 6.68 & 0.32 & 12.5 & 36.5 & 18.9 & 620 & 31.3 & 19.3 & 21.6 \\
\hline $\mathrm{Ash}+\mathrm{CAN}$ & 6.69 & 0.32 & 12.7 & 37.0 & 19.5 & 626 & 31.7 & 19.3 & 21.8 \\
\hline Ash+B1 & 6.74 & 0.33 & 13.2 & 36.8 & 19.7 & 649 & 32.0 & 19.9 & 23.4 \\
\hline Ash+BS1 & 6.97 & 0.32 & 12.9 & 37.5 & 19.4 & 640 & 32.4 & 19.7 & 18.0 \\
\hline Ash+BMG1 & 6.78 & 0.32 & 12.9 & 37.6 & 19.58 & 645 & 32.5 & 19.8 & 18.3 \\
\hline \multicolumn{10}{|c|}{ mg/kg d.w. plant biomass } \\
\hline Control & $<\mathrm{MDL}$ & 0.31 & 0.04 & 1.47 & 6.06 & 72.8 & 1.19 & 0.46 & 35.1 \\
\hline Control CAN & $<\mathrm{MDL}$ & 0.45 & 0.04 & 2.20 & 6.31 & 89.7 & 1.49 & 0.80 & 54.6 \\
\hline Ash & 0.01 & 0.42 & 0.06 & 1.55 & 7.22 & 85.6 & 1.08 & 0.79 & 32.0 \\
\hline $\mathrm{Ash}+\mathrm{CAN}$ & 0.01 & 0.39 & 0.05 & 1.77 & 8.25 & 89.5 & 0.94 & 1.00 & 38.2 \\
\hline Ash+B1 & 0.01 & 0.42 & 0.05 & 1.50 & 8.10 & 94.1 & 1.04 & 1.07 & 35.9 \\
\hline Ash+BS1 & 0.03 & 0.38 & 0.08 & 1.99 & 7.52 & 91.7 & 1.04 & 0.83 & 33.1 \\
\hline Ash+BMG1 & 0.03 & 0.33 & 0.06 & 1.69 & 7.14 & 85.7 & 1.06 & 0.63 & 30.6 \\
\hline \multicolumn{10}{|c|}{ mg/kg d.w. ash } \\
\hline Biomass ash* & 0.56 & 1.59 & 2.81 & 10.8 & 140 & 299 & 26.3 & 3.35 & 269 \\
\hline
\end{tabular}

* biomass ash after combustion of soybean residues. MDL-method detection limit

\section{Conclusions}

The use of biomass ash alone and in combination with three Bacillus isolates resulted in increased barley yields as well as improved soil and plants quality. The addition of biomass ash studied leads to an increase in soil $\mathrm{pH}$ and therefore can be used as fertilizer on acidic soils. The content of trace elements did not exceed the maximum allowed concentrations for both soil and plants. Moreover, ash contributed to an increase in the yield, the content of phosphorus and potassium in barely. In addition, the use of combinations of ash and microorganisms such as isolates Bacillus sp. B1 and Bacillus sp. BS1 improved the quality of the plants in terms of nitrogen and carbon content. This preliminary pot experiment shows that the synergistic effect 
of biomass ash and the microorganisms studied can provide green farming approach to reduce the need for chemical fertilizers and improve the quality of crops. Further research on a field scale is needed to validate the results of the preliminary pot-experiment.

Acknowledgment: Research was financed by the Ministry of Education, Science and Technological development of the Republic of Serbia (agreement no. 451-03-9/2021-14/200011)

\section{References}

Adriano DC. (2001). Trace elements in terrestrial environments: biogeochemistry, bioavailability, and risks of metals, 2001, doi:10.1007/978-0-387-21510-5.

Ali A, Phull AR, Zia M, Shah AMA, Malik RN. (2015). Phytotoxicity of River Chenab sediments: In vitro morphological and biochemical response of Brassica napus L. Environmental Nanotechnology, Monitoring and Management. 4, 74-84.

Brannvall E, Nilsson M, Sjoblom R, Skoglund N, Kumpiene J. (2014). Effect of residue combinations on plant uptake of nutrients and potentially toxic elements. J Environ Manage. 132, 287-295. http://dx.doi.org/10.1016/j.jenvman.2013.11.024

Brannvall E, Wolters M, Sjoblom R, Kumpiene J. (2015). Elements availability in soil fertilized with pelletized fly ash and biosolids. J Environ Manage. 159, 27-36. http://dx.doi.org/10.1016/j.jenvman.2015.05.032.

Buntić A, Stajković-Srbinović O, Knezević M, Kuzmanović D, Rasulic N, Kuzmanović Đ, DimitrijevićBranković S, Delić D. (2019). The effect of bacterial isolates from rhizosphere soils on wheat and barley seed germination. Soil and Plant. 68(2), 1-11.

Cakmakci R, Dönmez M F, Erdoğan Ü. (2007). The effect of plant growth promoting rhizobacteria on barley seedling growth, nutrient uptake, some soil properties, and bacterial counts. Turkish Journal of Agriculture and Forestry. 31(3), 189-199.

Cuske M, Marcinkiewicz M, Szopka K, Karczewska A, Pora E. (2013). The influence of Oława zinc smelter on soil environment of adjacent areas in the light of total content of heavy metals in surface levels of Oława soils. Paper of Uni Zielona Góra / Environ Eng Series. 149(29), 42-50 (in Polish, with English summary).

Dugalić G, Katić S, Vasiljević S, Gajić B, Lazarević B, Đalović I. (2006). Effects of liming on changes in pseudogley agrochemical properties and alfalfa yield, Zemljište i biljka, 55(3), 249-257. 
Freire M, Lopes H, Tarelho LA. (2015). Critical aspects of biomass ashes utilization in soils: Composition. leachability. PAH and PCDD/F. Waste Manag. 46, 304-315. http://dx.doi.org/10.1016/j.wasman.2015.08.036.

Horneck DA. and Miller RO. (1997). Determination of total nitrogen ln plant tlssue. In: Y kalra (ed.), Handbook of Reference Methods for Plant Analysis, CRC Press, taylor \& Francis Group, boca Raton, Florida, USA, pp. 75-83.

Jakšić SP, Vučković SM, Vasiljević SL, Grahovac NL, Popović VM, Dozet GK. (2013). Akumulacija teških metala u Medicago sativa L. i Trifolium pratense L. na kontaminiranom fluvisolu. Chemical Industry/Hemijska Industrija. 67(1), 95-101.

Knežević M, Buntić A, Stajković-Srbinović O, Mihajlovski K, Rasulić N, Stanković S, Delić D. (2019). Antagonistic effect of soil-borne Bacillus isolates against Fusarium infection and induction of wheat seed germination. 1st International Symposium: „Modern Trends in Agricultural Production and Environmental Protection”. 2-5 July. 2019. Tivat. Montenegro. Proceedings: 183-196.

Knežević MM, Stajković-Srbinović OS, Assel M, Milić MD, Mihajlovski KR, Delić DI, Buntić AV. (2021). The ability of a new strain of Bacillus pseudomycoides to improve the germination of alfalfa seeds in the presence of fungal infection or chromium. Rhizosphere, 18, 100353.

Loo SV and Koppejan J. (2008). The handbook of biomass combustion and co-firing. Earthscan. London. Milagres AMF, Machuca A, Napoleao D. (1999). Detection of siderophore production from several fungi and bacteria by a modification of chrome azurol $\mathrm{S}$ (CAS) agar plate assay. J Microbiol Methods. 37, 1-6.

Miller RO. (1998). Determination of dry matter content of plant tissue: gravimetric moisture. In: Y kalra (ed.), Handbook of Reference Methods for Plant Analysis, CRC Press, taylor \& Francis Group, boca Raton, Florida, USA, pp. 51-52).

Nelson DW, Sommers LE. (1996). Total carbon, organic carbon, and organic matter. In: D L Sparks (Ed.), Methods of Soil Analysis, part 3, SSSA, Madison, Wiskonsin, USA, pp. 961-1010.

Obernberger I and Supancic K. (2009). Possibilities of ash utilization from biomass combustion plants. In: Proceedings of the $17^{\text {th }}$ European Biomass Conference \& Exhibition, June/July 2009, Hamburg, ETARenewable Energies (Ed.), Italy.

Official Gazette of the Republic of Serbia No 23/1994. Rulebook on permitted quantities of dangerous and harmful substances in soil and water for irrigation and methods of their testing (In Serbia).

Official Gazette of the Republic of Serbia No 4/2010-30, 113/2012-11, 27/2014-17, 25/2015-85, 39/201641, 54/2017-29. Rule book of the quality of animal feed (In Serbia). 
Ozturk A, Caglar O, Sahin F. (2003). Yield response of wheat and barley to inoculation of plant growth promoting rhizobacteria at various levels of nitrogen fertilization. Journal of Plant Nutrition and Soil Science. 166(2), 262-266.

Pandey S, Gupta S. (2020). Diversity analysis of ACC deaminase producing bacteria associated with rhizosphere of coconut tree (Cocos nucifera L.) grown in Lakshadweep islands of India and their ability to promote plant growth under saline conditions. J. Biotechnol. 324, 183-197.

Pesonen J, Kuokkanen V, Kuokkanen T, Illikainen M. (2016). Co-granulation of bio-ash with sewage sludge and lime for fertilizer use. Journal of Environmental Chemical Engineering. 4(4), 4817-4821. http://dx.doi.org/10.1016/j.jece.2015.12.035

Riehm H (1958). Die Ammoniumlaktatessigsauremethode zur bestimmung der leichtloslichen phosphorsure in karbonathaltigen boden. agrochimica 3(1), 49-65.

Rokhbakhsh-Zamin F, Sachdev D, Kazemi-Pour N, Engineer A, Pardesi K, Zinjarde S, Dhakephalkar P, Chopade B. (2011). Characterization of Plant-Growth-Promoting Traits of Acinetobacter Species Isolated from Rhizosphere of Pennisetum glaucum. Journal of Microbiology and Biotechnology. 21(6), 556-566.

Saletnik B, Zagula G, Bajcar M, Czernicka M, Puchalski C. (2018). Biochar and Biomass Ash as a Soil Ameliorant: The Effect on Selected Soil Properties and Yield of Giant Miscanthus (Miscanthus x giganteus). Energies MDPI, 11, 2535; doi:10.3390/en11102535.

Saljnikov E, Repić B, Koković N, Čakmak D, Saljnikov A, Dakić D. (2018). Utilization of biomass ash after combustion in an electric power plant: effect on soil and plant quality. $10^{\text {th }}$ International Congress on "The soil resources and environment conservation", Almaty, Kazakhstan, 17-19 October, Proceedings, 236-239.

Schulin R, Johnson A, Frossard E. (2010). Trace element-deficient soils. In: Hooda PS (ed) Trace elements in soils. Wiley-Blackwell Publishing, Chichester, pp 175-197

Sherene T. (2010). Mobility and Transport of Heavy Metals in Polluted Soil Environment. Biological Forum-An International Journal. 2, 112-121.

Sikirić B, Stajković-Srbinović O, Čakmak D, Delić D, Koković N, Kostić-Kravljanac V, Mrvić V. (2015). Macronutrient contents in the leaves and fruits of red raspberry as affected by liming in an extremely acid soil. Plant Soil Environ. 61(1), 23-28.

Simić AS, Vučković SM, Dželetović ŽS, Sokolović DR, Anđelković BS, Delić DI, Mandić VT. (2015). Upotrebna vrednost i akumulacija teških metala u krmnim travama odgajenim na pepelištu termoelektrane. Chemical Industry/Hemijska Industrija. 69(5), 459-467

SRPS ISO 11464:2004. Soil Quality_Determination of ph; Institute for Standardization: Belgrade, Serbia, 2007. 
SRPS ISO 11466:2004 Soil Quality_Extraction of Trace Elements Soluble in Aqua Regia; SRPS: Institute for Standardisation of Republic of Serbia: Belgrade, Serbia, 2004.

Stajković O, Delić D, Jošić D, Kuzmanović Đ, Rasulić N, Knežević-Vukčević J. (2011). Improvement of common bean growth by co-inoculation with Rhizobium and plant growth-promoting bacteria. Romanian Biotechnological Letters. 16(1), 5919-5926.

Stevanović D, Nakalemić A, Pešić R. (2002). Sadržaj najvažnijih elemenata i njihova poziciona pristupačnost u metohijskim vinogorjima. XIV savetovanje vinogradara i vinara Srbije. Poljoprivreda. 390-393, 196-201.

WRB (2015) World Reference Base for Soil Recourses. Food and Agriculture Organization of the United Nations. Rome, 2015

Zhang Z, He F, Zhang Y, Yu R, Li Y, Zheng Z, Gao Z. (2018). Experiments and modelling of potassium release behavior from tablet biomass ash for better recycling of ash as eco-friendly fertilizer. Journal of Cleaner Production. 170, 379-387. 


\section{Zajednički efekat Bacillus izolata i pepela na kvalitet zemljišta i biljke: Preliminarni ogled u saksijama sa analizom potencijalno toksicnih elemenata}

Aneta Buntić*, Sonja Tošić Jojević, Magdalena Knežević, Marina Jovković, Biljana Sikiric, Nikola Koković, Elmira Saljnikov

Institut za zemljište, Teodora Drajzera 7, 11060 Beograd, Srbija

*Autor za kontakt: Aneta Buntić, anetabuntic@gmail.com

\section{Izvod}

Primena pepela dobijenog sagorevanjem biomase u poljoprivredi može imati niz prednosti kao što su poboljšanje kvaliteta zemljišta i ekološko odlaganje pepela. Štaviše, u kombinaciji sa mikrobiološkim inokulantima, pepeo može pozitivno da deluje na rast bijaka. Ova studija istražuje efekat pepela i tri inokulanata izolata Bacillus-a na kvalitet zemljišta i ječma. Eksperiment u stakleniku sa saksijama je uključio pet tretmana i dve kontrole: zemljište bez dodataka i sa dodatkom mineralnog đubriva (krečni amonijum nitrat, KAN). Tretmani su uključivali zemljište (3 kg/saksiji) i pepeo (30 g/saksiji) sa ili bez dodatka KAN-a ili sa dodatkom bakterijskog inokuluma. Pepeo je prikupljen nakon sagorevanja sojine slame. Bacillus-i su izolovani iz rizosfere lucerke. Prisustvo PGP osobina (indol-3-sirćetna kiselina i siderofore) za tri Bacillus izolata (B1, BS1, BMG1) potvrđena je kvantitativnim testovima. Uzorci pepela, zemljišta i biljka su analizirani: ukopan $\mathrm{N}, \mathrm{C}, \mathrm{S}$ i dostupi $\mathrm{P}_{2} \mathrm{O}_{5}$ i $\mathrm{K}_{2} \mathrm{O}$, kao i sadržaj potencijalno toksičnih i opasnih mikroelemenata (As, $\mathrm{Cd}, \mathrm{Co}, \mathrm{Cr}, \mathrm{Cu}, \mathrm{Mn}, \mathrm{Ni}, \mathrm{Pb}, \mathrm{Zn}$ ). Inokulacija semena sa Bacillus inokulumima (in vitro) pokazala je značajan efekat na rast klijanaca u poređenju sa neinokulisanom kontrolom. Dodatak pepela je značajno redukovao kiselost zemljišta i povećao sadržaj dostupnog fosfora i kalijuma u poređenju sa kontrolama, dok je kombinacija pepela i mikoorganizama povećala sadržaj fosfora u pređenju sa tretmanom gde je korišćen samo pepeo. Prinos biomase ječma je povećana duplo kada je tretirana pepelom i do $87.62 \%$ kada je tretirana sa pepelom+BMG1 u poređenju sa kontrolom. Najniži prinos je dobijen u tretmanu gde je korišćen samo KAN. Sadržaj potencijalnih toksičnih mikroelemenata u zemljištu i ječmu bio je ispod makismalno dozvoljenih koncentracija. Primena samo pepela je bila efikasna u pogledu hranljivih i fizičkih osobina zemljišta što je rezultiralo povećanju prinosa ječma. Međutim, primena pepela u kombinaciji sa izolatima Bacillus-a je dodatno pozitivno uticala na kvalitet zemljišta i biljke, što je dovelo do povećanja prinosa ječma u pređenju sa pepelom i KAN-om u kombinaciji. Ova studija je pokazala da pepeo biomase može da se koristi kao đubrivo u kiselim zemljištima sa niskim nutritivnim sadržajem sam ili u kombinaciji sa bakterijskim inokulantima. Zajednički efekat pepela i mikroorganizama može obezbediti ekološki pristup u poljoprivredi kako bi se smanjile potrebe za hemijskim đubrivima i rešili problemi odlaganja pepela.

Ključne reči: Bacillus, pepeo biomase, zemljište, ječam, nutrienti, elementi u tragovima

Received 02.09.2021

Revised 30.09.2021

Accepted 04.10.2021 